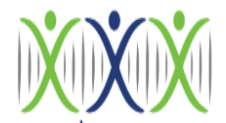

iRASD
Pakistan Journal of Humanities and Social Sciences

Volume 9, Number 3, 2021, Pages 469-481

Journal Homepage:

https://journals.internationalrasd.org/index.php/pjhss
PAKISTAN JOURNAL OF

HUMANITIES AND SOCIAL

SCIENCES (PJHSS)

\title{
Does Greenfield Foreign Direct Investment Inflow Contribute in Socioeconomic Development? Empirical Evidence from Developing Countries
}

\author{
Ali Raza ${ }^{1}$, Shahid Akbar ${ }^{2}$, Zahid Raza ${ }^{3}$ \\ ${ }^{1}$ Lecturer, Department of Management Sciences, The University of Haripur, Pakistan. \\ Email: alirazaeco@gmail.com \\ ${ }^{2}$ Assistant Professor, Department of Economics, University of Swabi, Pakistan. \\ Email: shahidakbar@uoswabi.edu.pk \\ ${ }^{3}$ M.Phil. Scholar, Department of Criminology, University of Karachi. Pakistan. \\ Email: z4zahidraza@gmail.com
}

\section{ARTICLE INFO}

Article History:

Received:

Revised:

Accepted:

November 11, 2021

December 10, 2021

December 11, 2021

Available Online: December 28, 2021

Keywords:

Human Development Index HDI

Greenfield-FDI

Education

Health

Remittances

Foreign Development Assistance

\section{JEL Classification Codes:}

F24, F35, I10, I15, I25, I31

\section{ABSTRACT}

This study aims to assess the impact of Greenfield-Foreign Direct Investment (FDI) inflows on the socio-economic development of ten developing countries. Developing economies rely on investment from developed countries, especially Greenfield investment. Greenfield investment is the new capital inflow to the host country's economy that helps to improve economic activities, boosts economic growth, and improves socio-economic welfare. This study has used Greenfield investment as the target-independent variable and other controlled variables remittances, aid, inflation, population, and trade openness. At the same time, socio-economic development, health, economic growth, and education are dependent variables. For this purpose, Pooled Mean Group (PMG) technique/Panel Autoregressive-Distributed Lag (ARDL) has applied for estimation purposes from 1990 to 2017. The empirical findings have shown that Greenfield-FDI has a longterm statistically significant and positive effect on economic growth, health, education, and socio-economic development. In comparison, remittances and official development assistance have positive and negative impacts on the study's dependent variables. The population also has a positive effect, whereas inflation and trade have mixed results. Outcomes of this study advise that policymakers should adopt attractive investment policies to enhance more foreign investment and utilize it efficiently, thereby promoting sustainable development. The government should announce firms to invest in human capital, which will impact productivity.

(c) 2021 The Authors, Published by iRASD. This is an Open Access Article under the Creative Common Attribution Non-Commercial 4.0

Corresponding Author's Email: shahidakbar@uoswabi.edu.pk

\section{Introduction}

Developing countries have been experiencing a macroeconomic transformation of varied and dynamic nature for the last three decades. These countries are liberalizing trade and investment borders to draw potential investors from developed countries around them. This rapid phase of globalization has resulted in a significant global investment in Greenfield-FDI, attracting the attention of macroeconomic researchers. Most developing countries have improved their socio-economic development through Greenfield-FDI investment (Sawyer et al., 2010).

Mergers and Acquisition (M\&A), Brownfield-FDI (BFDI), and Greenfield-FDI (GFDI) are different forms of FDI (Bayar, 2017). Firms of developed countries select to spend less on M\&A and more on Greenfield-FDI. Developed countries invest in the form of Greenfield-FDI in developing countries. As a result, the income difference between developed and developing countries decreases, further decreasing Greenfield-FDI (Stepanok, 2015). Greenfield-FDI leads 
to growth and investment by launching new technologies and adds to the business's productivity by creating jobs (Meyer, 2004).

Greenfield-FDI is developed in various sectors from which not only companies, but host countries, also benefit. Many multinational corporations and corporations are investing in different FDI modes in developing countries, but investment by companies in Greenfield-FDI are the most productive and active ones (Stepanok, 2015). Globally, the value of GreenfieldFDI schemes rose by 7\% (i.e., to US\$ 828 billion in 2016 in comparison with US\$ 645 billion in 2012) with investments in the principal sector of Greenfield-FDI is amounting to US\$ 54 billion, services sector to US\$ 481 billion, and manufacturing sector to US\$ 292 billion (UNCTAD, 2017). Generally, around the globe, Greenfield-FDI falls by $15.2 \%$, to US $\$ 662.6$ billion, in capital investment (FDI, 2018).

Table 1: Greenfield-FDI Flow to World, Developed Countries, Developing Countries and Asian Developing Countries (US\$ billions)

\begin{tabular}{|c|c|c|c|c|c|c|c|c|}
\hline GFDI Details & $\begin{array}{l}\text { 1990- } \\
2011 *\end{array}$ & 2012 & 2013 & 2014 & 2015 & 2016 & 2017 & 2018 \\
\hline World & 814.18 & 1246.49 & 1162.86 & 910.41 & 1186.18 & 980.63 & 735.85 & 713.73 \\
\hline Developed C's & 336.65 & 591.49 & 463.03 & 303.64 & 500.49 & 326.85 & 143.47 & 131.96 \\
\hline Developing C's & 477.52 & 655.00 & 699.83 & 606.77 & 685.69 & 653.78 & 592.37 & 581.77 \\
\hline Asian Developing C's & 46.35 & 71.07 & 75.37 & 65.74 & 56.27 & 47.64 & 67.74 & 67.52 \\
\hline
\end{tabular}

Source: Data taken from UNCTAD (2020) and WDI (2020). *Average data from 1990-2011.

Table 1 shows Greenfield-FDI inflows from 1990-2017 to Asian developing countries, developing countries, developed countries, and the world. After 2015, there was a decline in the flow of Greenfield-FDI to the world and the rest of developing and developed countries. The total flow of Greenfield-FDI to the world was about US\$ 910 billion in 2014 that decreased to US\$ 736 billion in 2017, out of which US\$143 billion was to developed countries, US\$592 billion to developing countries, and 67.74 US\$ billion to Asian developing countries.

Greenfield-FDI is considered a tool to increase capital to the existing stock of host country capital and productivity (Kim, 2009). It is believed that Greenfield-FDI is the facility provided to the host country in the shape of new investment and construction of new facilities. If Greenfield-FDI only absorbs and uses host country resources and its trained and skilled labor and advanced technology cannot be efficiently used, then it would lead to negative investment and would have Dutch disease effect (Nunnenkamp \& Spatz, 2003). Greenfield-FDI would spur the growth of a host country's economy (H. Luu, 2016) that would further improve a host country's society (Lehnert et al., 2013). (Loayza et al., 2004) defined Greenfield-FDI as the differences between total M\&A sales and total FDI inflows, later on followed by Harms and (Harms \& Méon, 2011) and (Wang \& Wong, 2009).

For many decades, there has often been controversy about selecting a common and reliable metric to assess socio-economic development (Qizilbash, 2001). Realistic assessment of the country's socio-economic development allows policymakers to propose more realistic results-oriented strategies to boost well-being. Until the late 1970s, Gross Domestic Product (GDP) based on National Accounting System (NAS) was used to assess the socio-economic growth of a country by researchers. The problem with this tool is that it is a one-dimensional measurement of socio-economic development that is a flexible event, though agreeing that it is a one-dimensional measurement of socio-economic development still strongly argues that this tool can seriously mislead the level of human development (Krugman \& Mankiw, 1995).

Many scholars have found several conceptual problems when using GDP per capita or simply GDP as a measuring tool for the socio-economic development of a country (Kuznets, 1947; Nordhaus et al., 1973; Sen, 2000). Modern economists assume that growth in the economy is the growth of humans rather than the production of objects (Todaro \& Smith, 2015). The socio-economic development should take place in the broader context, such as access to technological schooling, an adequate living standard, and good health facilities (Sen, 1998). Many researchers have contributed to calculating a country's socio-economic growth by taking into account various socio-economic instruments such as schooling, health, life expectancy, poverty, housing, nutrition, crime, agricultural products, and environmental pollution (Azam \& Gavrila, 2015; Mukherjee, 2017; Raza et al., 2021). The definition of the 
Human Development Index (HDI) introduced by (Haq, 1995) is a combination of health and education and standard of living adopted by the United Nations (UN) as a standard metric for computing socio-economic development. HDI takes a value between 0 and 1 , with the highest value suggesting the higher welfare of a country. Countries with an HDI value of 0.80 or above sit at the upper tail of the socio-economic development continuum, while those with an HDI value of 0.50 are at the lower end of the socio-economic development continuum (Anand \& Sen, 1994).

Developing countries seem to be compelling cases for conducting an empirical study to examine the relationship between Greenfield-FDI and socio-economic development. One substantial justification for this study is the higher level of Greenfield-FDI inflows to these countries. There is a void in the literature on the linkage between Greenfield-FDI and socioeconomic development and its indices in developing nations in Asia. This field is overlooked in the literature, and this is the reason for filling this void. The key objective is to empirically evaluate the impact of Greenfield-FDI on economic growth, socio-economic development, health, and education. The sample countries for this study are Armenia, Indonesia, Iran, Jordan, Kazakhstan, Malaysia, Philippines, Sri Lanka, Thailand, and Turkey, primarily Asian developing countries. The sampled countries are selected because these countries show improvement in economic growth and economic development.

This study is different from other studies in many aspects. First, this study used solid Greenfield-FDI data by following (Loayza et al., 2004) methodology. The authors subtract M\&A from a total inflow of FDI to the host country. Second, this study used HDI as a proxy for socioeconomic development and its components like income index as a proxy for living standard, education index as a proxy for means years of schooling, and expected years of education and health index as a proxy for life expectancy at birth. Third, this study chose those developing countries that show improvement in the sampled time series years.

The rest of this paper is set out as; literature review, methodology, model specification, and techniques used in the estimation of data analysis of this study and followed by results in discussion while the last summary and conclusion of this study are explained.

\section{Literature Review \\ 2.1. Theoretical Literature}

Harrod (1972) and Domar (1946) present a classical model and incorporate capital and labor for the first time in a production function. Later on, most economists included capital in its different forms like foreign aid, remittances, and FDI. (Vernon, 1966) presented product life cycle theory which states that due to its comparative benefit of factor endowment, country production at its initial stage serves the local market and enjoys a competitive advantage in its local technology. (Dunning, 1979) stresses the benefits of ownership, localization, and internalization by which firms can invest in host countries and take advantage of these three properties. Later (Mankiw et al., 1992) have incorporated the role of human capital in growth models. The pioneers of endogenous growth theory (Romer, 1986, 1994) have opened ideas on how human capital can increase per capita income. Barro (1991) further provided evidence of how necessary human capital is in developing a country.

\subsection{Empirical Literature}

Several scholars focused on the FDI-growing nexus in literature and explored that FDI inflow contributes to the growth of the economy of host developing nations. Very few researchers studied different forms of FDI and reported the effects of Brownfield-FDI and Greenfield-FDI. A pioneering study is carried out by (Moon et al., 2003) using panel data and finds a positive impact of Brownfield-FDI on the growth of the economy of China, South Korea, and Hong Kong. The authors used data for 1999-2002 by applying the diamond model and confirming that Brownfield-FDI spurs the growth of the economy of these countries.

Some of the researchers concluded that Greenfield-FDI had a positive relationship with the economy's growth, as (Loayza et al., 2004) found that growth rate was positively linked to both Greenfield-FDI and Brownfield-FDI. This relationship was measured in 72 developing countries for the years 1978-2003 using the Autoregressive technique. By Granger's causality checks, (Neto et al., 2008) show that there is unidirectional causation of economic growth to Greenfield-FDI for both developed and developing countries for the years 1996-2006. It is also 
projected that Greenfield-FDI has a positive impact on the development of the economy in all 53 countries. In contrast, in developing countries, it is calculated that M\&A harms the growth rate.

Slangen \& Hennart (2008) carried out a detailed survey through the mail from 35 countries, including 248 foreign investments made by 159 multinational companies. They justified the preference of international companies to invest in culturally distant lands through Greenfield-FDI. Similarly, (Wang \& Wong, 2009) made suggestions that Greenfield-FDI accelerates the growth of the economy, while M\&A is only beneficial if the number of capital increases. From 1987 to 2001, authors used instrumental tests and worked on a sampled combination of 84 developing and developed countries and concluded that Greenfield promoted both developed and developing countries' growth. (Almsafir et al., 2011) investigated Malaysia's economy from 1970 to 2009 using a bound test method and analyzed that Greenfield-FDI promotes economic growth and supports boosting the development of the economy.

Harms \& Méon (2011) used the generalized method of moments (GMM) technique and reported that M\&A and Greenfield-FDI have a significant economic growth relationship. Using data from 1978-2005 and taking a sample of 78 middle-income and low-income countries, the study further revealed that the economic growth impact of M\&A is less than that of GreenfieldFDI. (Byun et al., 2012) found that GDP per capita has a more significant M\&A association than Greenfield-FDI from 1990 to 2009 using Sys-GMM for 40 emerging economies. Moreover, inflation harms M\&A relative to Greenfield-FDI, although the size of the population has a positive impact on M\&A and Greenfield-FDI. Similarly, (Zhuang \& Griffith, 2013) found that Greenfield-FDI inflows had a substantial and robust effect on income inequality. Brownfield-FDI inflows had no considerable influence on income inequality when working for a sample of 93 countries in 1990-2009. The same conclusion was supported by the study conducted by (Harms \& Méon, 2011). The authors used the GMM estimation methodology while analyzing the Middle East and North Africa (MENA) countries from 1978 to 2015. They concluded that Greenfield-FDI had a more positive effect on growth rather than M\&A.

Luu (2016) argued that M\&A and Greenfield-FDI had made a substantial contribution to increasing economic development. Emerging countries could benefit more if human capital levels were increased while taking the time of 2003-2014 and a sample of emerging countries, using a two-step GMM estimator. (Marinescu, 2016) contrasted the analysis of characteristics of Greenfield-FDI and M\&A used for investing in foreign countries by transnational corporations (TNCs). The author claimed that investments in leading technology and research and development (R\&D), preferring long-term growth, will be favored by Greenfield-FDI. (Azam \& Ahmed, 2015) found that FDI inflow has a positive and significant effect on the economic development of selected independent states of the Commonwealth. (Bahattab et al., 2016) found that direct foreign investment positively contributed to the economic growth of Yemen from 2003 to 2014. (Azam, 2016) observed the inward FDI has a significantly positive effect on the economic development of 20 OIC countries from 1986 to 2012.

Bayar (2017) examined the effect of Greenfield-FDI and M\&A on the economic growth of the European Union (EU) sample of countries from 2003 to 2015. The study showed that both M\&A and Greenfield-FDI have a positive impact on economic growth. Further results have shown a one-way causality from M\&A and Greenfield-FDI to economic development based on Basher and Westerlund's co-integration experiments. (Amoroso \& Castello, 2018) used the Feasible Generalized Least Squares (FGLS) estimation technique to examine the relationship between work polarization and Greenfield-FDI in European countries. The authors reported from 2003 to 2014 that Greenfield-FDI had a positive effect on job polarization for Information and Communication Technology (ICT).

Luu et al. (2019) have examined the effects of corruption in developing and developed countries. Sys-GMM method was used in 131 countries sampled from 2003 to 2015. The results indicated that corruption in developing countries has a significant positive effect on GFDI but significantly negatively impacts developed countries. Additional findings have shown that population has a marginal impact on GFDI of developed countries. (Raza et al., 2020) studied the effect of investments in Greenfield on the welfare of developing countries in Africa 
for the period 1998-2017. The authors used the GMM technique and analyzed that Greenfield investment positively correlates with socio-economic development, economic growth, health, and education. Similar findings were also initiated in the study of (Raza et al., 2020) by examining the impact of Greenfield investment on the socio-economic development of Pakistan. The authors used time-series data from 1990-2017 and applied ARDL and ECM models. Results of the study revealed a long-run association between Greenfield investment, health, and socio-economic development.

Some researchers have examined lack or negative effect of Greenfield-FDI on economic development. (Eren \& Zhuang, 2015) used unbalanced GMM estimator data panel and examined that GFDI had a negative influence on domestic investment, while M\&A had almost no impact on domestic investment for a sample of 100 developing countries from 2003 to 2011. (Ashraf \& Herzer, 2014) concluded that both Brownfield-FDI and Greenfield-FDI had no major effect on economic development of 12 countries of European Union for the years 19992010. (Ashraf et al., 2016) confirmed that M\&A has had a significant influence on overall factor productivity for developed nations for 123 developing and developed countries for the years 2003-2011. The results showed that Greenfield-FDI was ineffective in the total study, while M\&A had a positive impact on productivity in a total sample. (Stepanok, 2015) analyzed that $M \& A$ lose competition in a monopoly market, but in the presence of two symmetrical countries with Greenfield investment and M\&A, the businesses that prefer Greenfield to invest will reduce host country's efficiency and welfare.

This study is closed to (Luu, 2016) and (Raza et al., 2021) but different in many aspects. This study has focused on solid Greenfield-FDI data by following the method of (Loayza et al., 2004), is to subtract M\&A from total FDI inflow. Second, this study has focused on Selected Asian developing countries, which are emerging economies while former studies focused on combination of least developed and developing countries. To minimize the difference between these countries growth impact, this study is carried out. Third, the study sought to evaluate the effect of Greenfield-FDI on health, growth, education and socioeconomic development, while former studies focused on economic growth only.

\section{Empirical Methodology and Data}

Methodology and variables are chosen based on their significance on a theoretical and empirical basis. This study has a small cross-section size of 10 countries and a large timeseries size of 28 years of data from 1990 to 2017. The sampled time is selected due to the availability of data.

\subsection{Empirical Model}

The classical production function is;

$$
Y=f(K, L)
$$

As suggested by (Feder, 1983), the standard aggregated production function and introducing the Greenfield-FDI, remittances, foreign aid, inflation, trade openness, and population as independent variables, and the function becomes as,

$$
Y=f(G F D I, \text { re } m, \text { aid, trade, pop, inf })
$$

Transforming and taking the derivative of the above function;

$$
Y=\alpha_{0} G F D I+\alpha_{1} r e m+\alpha_{2} \text { aid }+\alpha_{3} \text { trade }+\alpha_{4} p o p+\alpha_{5} \text { inf }
$$

From equation (3), it is expected that the targeted variable and each controlled variable will have a positive sign of partial derivatives of its role.

\subsubsection{Model Specification}

The goal of this research is to study the impact of GFDI on sampled Asian developing countries living standards, health, education, and socioeconomic development based on the ARDL model (Pesaran, 1997; Pesaran et al., 1999, 2001; Pesaran \& Smith, 1995). This modeling method has many advantages over other methods and can be implemented 
irrespective of the strictly interconnected variables of order 0 or 1 . Another benefit of this model is that the results would be effective even if the independent variables are endogenous (Pesaran et al., 2001). Also, this model is robust when there is a single long-run relationship between the variables under consideration in a small sample size.

The generalized ARDL model is specified as; $Y_{i t}=\sum_{j=1}^{p} \delta_{i j} Y_{i, t-j}+\sum_{j=0}^{q} \beta_{i j}^{\prime} X_{i, t-j}+\varphi_{i}+\varepsilon_{i t}$ (4) Where $Y_{i t}$ and $X_{i, t-j}$ are dependent variable and the vector of independent variables respectively purely of integrated of order 0 and 1 . And $\varphi_{i}$ is the unit-specific fixed effect and $\varepsilon_{i t}$ is the error term.

The re-parameterized ARDL error correction model (ECM) is stated as;

$\Delta Y_{i t}=\theta_{i}\left[Y_{i, t-1}-\lambda_{i}^{\prime} X_{i t}\right]+\sum_{j=1}^{p-1} \xi_{i j} \Delta Y_{i, t-j}+\sum_{j=0}^{q-1} \beta_{i j}^{\prime} \Delta X_{i, t-j}+\varphi_{i}+\varepsilon_{i t}$

Where $\theta_{i}$ shows the group-specific speed of adjustment coefficient and $\lambda_{i}^{\prime}$ is the vector of long-run relationships. $\left[Y_{i, t-1}-\lambda_{i}^{\prime} X_{i t}\right]$ is the error correction term and $\xi_{i j}, \beta_{i j}^{\prime}$ are the coefficients of short-run dynamic.

$$
\begin{aligned}
& \Delta e d u_{i t}=\theta_{i}\left[e d u_{i, t-1}-\lambda_{i}^{\prime}(G F D I, r \text { e } m, \text { aid }, \text { trade, pop }, \text { inf })_{i t}\right]+\sum_{j=1}^{p-1} \xi_{i j} \Delta e d u_{i, t-j}+ \\
& \sum_{j=0}^{q-1} \beta_{i j}^{\prime} \Delta(G F D I, r \text { e } m, \text { aid,trade, pop, inf })_{i, t-j}+\varphi_{i}+\varepsilon_{i t}
\end{aligned}
$$

$\Delta$ health $_{i t}=\theta_{i}\left[\right.$ health $\left._{i, t-1}-\lambda_{i}^{\prime}(\text { GFDI, re m, aid, trade, pop, inf })_{i t}\right]+\sum_{j=1}^{p-1} \xi_{i j} \Delta$ health itt-j +

$\sum_{j=0}^{q-1} \beta_{i j}^{\prime} \Delta(G F D I, \text { e } m, \text { aid, trade, pop, inf })_{i, t-j}+\varphi_{i}+\varepsilon_{i t}$

$\Delta_{\text {income }}{ }_{i t}=\theta_{i}\left[\right.$ income $\left._{i, t-1}-\lambda_{i}^{\prime}(\text { GFDI }, \text { re } m, \text { aid }, \text { trade, pop, inf })_{i t}\right]+\sum_{j=1}^{p-1} \xi_{i j} \Delta$ income $_{i, t-j}+$

$\sum_{j=0}^{q-1} \beta_{i j}^{\prime} \Delta(G F D I, \text { re } m, \text { aid, trade, pop, inf })_{i, t-j}+\varphi_{i}+\varepsilon_{i t}$

$\Delta h d i_{i t}=\theta_{i}\left[h d i_{i, t-1}-\lambda_{i}(G F D I, r \text { e } m, \text { aid, trade, pop, inf })_{i t}\right]+\sum_{j=1}^{p-1} \xi_{i j} \Delta h d i_{i, t-j}+$

$\sum_{j=0}^{q-1} \beta_{i j}^{\prime} \Delta(G F D I, \text { re } m, \text { aid, trade, pop, inf })_{i, t-j}+\varphi_{i}+\varepsilon_{i t}$

Based on equation (5), this study further used four more models for education, health, economic growth, and socioeconomic development. This ARDL PMG model has been used in (Raza et al., 2020) and (Asghar et al., 2020) research.

Classical economists considered capital as a backbone of growth. This research study is based on (Domar, 1946) and (Harrod, 1972) theory and was the first to incorporate capital in economic growth model. Developing countries lack capital, so their economies rely on the capital of developed countries. Despite this theory, this study used the theory of human capital to enhance the role of Greenfield-FDI in the education sector of developing countries. (Layard, 2009) in his research analyzed that investment in education and other welfare projects increases not only growth but also life expectancy.

\subsection{Estimation Techniques}

\subsubsection{Unit Root Testing and ARDL Model}

The analysis becomes complicated when some variables are integrated of order 0 , and some are integrated of order 1 . ARDL method is used to estimate panel data with nonstationary variables. This method estimates long-run in addition to short-run analysis of 
variables taken in the model. The stationarity of variables in a heterogeneous panel data set was a big problem. It was a severe issue with a significant time and small sample size of dynamic panels. This issue was solved by (Im et al., 2003), and this study used Pooled Mean Group (PMG) technique.

\subsection{Data and its Sources}

This research is organized to find out the influence of Greenfield-FDI on socio-economic development by taking data from different sources like (WDI, 2019), (UNDP, 2020), (UNCTAD S., 2020).

Table 2: List of Variables

\begin{tabular}{|c|c|c|c|c|}
\hline Variables & Narration & $\begin{array}{c}\text { Abbreviated } \\
\text { words }\end{array}$ & Units & Sources \\
\hline $\begin{array}{l}\text { Greenfield- } \\
\text { FDI }\end{array}$ & $\begin{array}{l}\text { FDI as Greenfield investment } \\
\text { in a country in USD. }\end{array}$ & GFDI & $\%$ GNI & $\begin{array}{l}\text { UNCTAD- } \\
2020\end{array}$ \\
\hline Remittances & $\begin{array}{l}\text { Migrants are moving payment } \\
\text { to their home land in USD. }\end{array}$ & Rem & Per capita & WDI-2020 \\
\hline Foreign Aid & $\begin{array}{l}\text { Official Development } \\
\text { Assistance as grants and } \\
\text { concessional aids in USD. }\end{array}$ & Aid & Per capita & WDI-2020 \\
\hline $\begin{array}{l}\text { Human } \\
\text { Development } \\
\text { Index }\end{array}$ & $\begin{array}{l}\text { HDI is measured as } \\
\text { geometric mean of GNI } \\
\text { index, education index and } \\
\text { index of life. }\end{array}$ & Hdi & Numeric & UNDP-2020 \\
\hline Education & $\begin{array}{l}\text { The Education Index is } \\
\text { geometric mean of actual } \\
\text { school years and predicted } \\
\text { school years. }\end{array}$ & Edu & Numeric & UNDP-2020 \\
\hline Health & $\begin{array}{l}\text { The longevity rate is } \\
\text { determined by } \\
\text { expectancy at birth. }\end{array}$ & health & Numeric & UNDP-2020 \\
\hline & $\begin{array}{l}\text { The Wealth Index is } \\
\text { determined by Gross National }\end{array}$ & & & \\
\hline $\begin{array}{l}\text { Standard of } \\
\text { Living }\end{array}$ & $\begin{array}{l}\text { Income per capita in } \\
\text { purchasing power parity } \\
\text { adjusted to USD. } \\
\text { Added imports and exports }\end{array}$ & income & Numeric & UNDP-2020 \\
\hline $\begin{array}{c}\text { Trade } \\
\text { Openness }\end{array}$ & $\begin{array}{l}\text { and divided by GDP (Real), } \\
\text { It's the proxy used for a } \\
\text { country overall trade. }\end{array}$ & trade & Per capita & WDI-2020 \\
\hline Inflation & $\begin{array}{l}\text { Inflation calculated as the } \\
\text { annual percentage index of } \\
\text { consumer prices. }\end{array}$ & Inf & Annual \% & WDI-2020 \\
\hline Population & $\begin{array}{l}\text { The number of people in a } \\
\text { nation. }\end{array}$ & Pop & $\begin{array}{c}\text { Total } \\
\text { populatio } \\
\mathrm{n}\end{array}$ & WDI-2020 \\
\hline
\end{tabular}

\section{Results and Discussion}

Table 3 displays the summary statistics of all variables used in this study. There are 280 observations of each variable, and has a variation lies between the maximum and minimum value. There is a lot of variation in remittances, aid, inflation, and population, but less or minimum variation can be seen in the rest of the variables. Table 4 is about the correlation between variables, as there is a negative correlation of Greenfield-FDI with health, remittances, education, aid, and trade while Greenfield-FDI has positive correlation with HDI, income and population. Income and population have a negative connection with remittances, whereas the rest of the variables positively correlate. Aid takes a negative correlation with the population and income. Still, a positive correlation with health, trade, education, and HDI Inflation takes only a positive correlation with trade. Still, a negative correlation can be seen with the rest of the variables. On the other side, trade positively correlates with all variables except population, which is harmful. Similarly, the population has a negative correlation with education, income, health, and HDI. 
Table 3: Summary Statistics

\begin{tabular}{cccccc}
\hline Variable & Obs & Mean & Std. Dev. & Min & Max \\
\hline GFDI $_{i t}$ & 280 & 0.262192 & 0.37534 & -1.1178 & 2.037201 \\
rem $_{i t}$ & 280 & 114.3895 & 167.4237 & 0.07703 & 757.6247 \\
aid $_{i t}$ & 280 & 30.58462 & 51.78814 & -21.719 & 306.1717 \\
rrade $_{i t}$ & 280 & 0.815908 & 0.425366 & 0.21018 & 2.632037 \\
pop $_{i t}$ & 280 & $5.75 \mathrm{E}+07$ & $6.25 \mathrm{E}+07$ & 2875581 & $2.64 \mathrm{E}+08$ \\
inf $_{i t}$ & 280 & 21.42872 & 54.46356 & -1.27121 & 350.123 \\
edu $_{i t}$ & 280 & 0.616018 & 0.101835 & 0.387 & 0.814 \\
income $_{i t}$ & 280 & 0.684139 & 0.08341 & 0.416 & 0.841 \\
health $_{i t}$ & 280 & 0.775946 & 0.052034 & 0.664 & 0.864 \\
$h d i_{i t}$ & 280 & 0.684007 & 0.060846 & 0.528 & 0.794 \\
\hline
\end{tabular}

Table 4: Correlation matrix of all variables

\begin{tabular}{|c|c|c|c|c|c|c|c|c|c|c|}
\hline & GFDI $_{i t}$ & $\mathrm{rem}_{i t}$ & $\operatorname{aid}_{i t}$ & $\operatorname{trade}_{i t}$ & pop $_{i t}$ & $\inf _{i t}$ & $e d u_{i t}$ & income $_{i t}$ & health $_{i t}$ & $h d i_{i t}$ \\
\hline $\mathrm{GFDI}_{i t}$ & 1 & & & & & & & & & \\
\hline $\mathrm{rem}_{i t}$ & -0.179 & 1 & & & & & & & & \\
\hline $\operatorname{aid}_{i t}$ & -0.216 & 0.722 & 1 & & & & & & & \\
\hline $\operatorname{trade}_{i t}$ & -0.011 & 0.115 & 0.190 & 1 & & & & & & \\
\hline pop $_{i t}$ & 0.432 & -0.331 & -0.383 & -0.436 & 1 & & & & & \\
\hline $\inf _{i t}$ & -0.172 & -0.147 & -0.092 & 0.235 & -0.135 & 1 & & & & \\
\hline$e^{e d u_{i t}}$ & -0.036 & 0.396 & 0.268 & 0.193 & -0.417 & -0.171 & 1 & & & \\
\hline income $_{i t}$ & 0.215 & -0.167 & -0.264 & 0.088 & -0.041 & -0.257 & 0.194 & 1 & & \\
\hline health $_{i t}$ & -0.018 & 0.364 & 0.267 & 0.169 & -0.322 & -0.116 & 0.446 & 0.377 & 1 & \\
\hline$h d i_{i t}$ & 0.076 & 0.296 & 0.149 & 0.243 & -0.366 & -0.196 & 0.834 & 0.651 & 0.702 & 1 \\
\hline
\end{tabular}

Table 5: Unit Root Testing

\begin{tabular}{|c|c|c|c|c|c|c|}
\hline \multirow[b]{2}{*}{ Variables } & \multicolumn{2}{|c|}{ IPS } & \multicolumn{2}{|c|}{ LLC } & \multicolumn{2}{|c|}{ Breitung } \\
\hline & Level & $1^{\text {st }}$ Difference & Level & $1^{\text {st }}$ Difference & Level & $1^{\text {st }}$ Difference \\
\hline $\mathrm{GFDI}_{i t}$ & $\begin{array}{l}-1.689 * * \\
(0.041)\end{array}$ & ----- & $\begin{array}{l}-2.0933^{* *} \\
(0.018)\end{array}$ & ----- & $\begin{array}{l}-2.3375^{* *} \\
(0.009)\end{array}$ & ----- \\
\hline $\operatorname{rem}_{i t}$ & $\begin{array}{l}2.3878 \\
(0.992)\end{array}$ & $\begin{array}{l}-6.5916 * * \\
(0.000)\end{array}$ & $\begin{array}{l}0.6129 \\
(0.730)\end{array}$ & $\begin{array}{l}-5.6731 * * \\
(0.000)\end{array}$ & $\begin{array}{l}1.4594 \\
(0.927)\end{array}$ & $\begin{array}{l}-5.4575 * * \\
(0.000)\end{array}$ \\
\hline $\begin{array}{l}\operatorname{aid}_{i t} \\
\operatorname{trade}_{i t}\end{array}$ & $\begin{array}{l}-1.0231 \\
(0.153) \\
-4.1408^{* *} \\
(0.000)\end{array}$ & $\begin{array}{l}-10.2899 * * \\
(0.000)\end{array}$ & $\begin{array}{l}-1.4226 \\
(0.077) \\
-5.8235 * * \\
(0.000)\end{array}$ & $\begin{array}{l}-7.5809 * * \\
(0.000) \\
----\end{array}$ & $\begin{array}{l}-0.9530 \\
(0.170) \\
1.2856 \\
(0.901)\end{array}$ & $\begin{array}{l}-2.3278 * * \\
(0.000) \\
-3.8985 * * \\
(0.000)\end{array}$ \\
\hline $\begin{array}{l}\operatorname{pop}_{i t} \\
\inf _{i t}\end{array}$ & $\begin{array}{l}2.2876 \\
(0.988) \\
-4.4277^{* *} \\
(0.000)\end{array}$ & $\begin{array}{l}-9.7065 * * \\
(0.000) \\
----\end{array}$ & $\begin{array}{l}-0.9385 \\
(0.174) \\
-3.6305^{* *} \\
(0.000)\end{array}$ & $\begin{array}{l}-9.9452 * * \\
(0.000) \\
----\end{array}$ & $\begin{array}{l}-0.9584 \\
(0.169) \\
-0.5046 \\
(0.307)\end{array}$ & $\begin{array}{l}-5.8352 * * \\
(0.000) \\
-4.4920 * * \\
(0.000)\end{array}$ \\
\hline $\begin{array}{l}\mathrm{edu}_{i t} \\
\text { income }_{i t}\end{array}$ & $\begin{array}{l}3.9121 \\
(0.995) \\
-2.8866^{* *} \\
(0.002)\end{array}$ & $\begin{array}{l}-8.0031 * * \\
(0.000) \\
----\end{array}$ & $\begin{array}{l}1.1017 \\
(0.864) \\
-6.9902 * * \\
(0.000)\end{array}$ & $\begin{array}{l}-8.8598 * * \\
(0.000) \\
----\end{array}$ & $\begin{array}{l}3.7473 \\
(0.991) \\
0.4157 \\
(0.661)\end{array}$ & $\begin{array}{l}-4.9621 * * \\
(0.000) \\
-5.6143 * * \\
(0.000)\end{array}$ \\
\hline $\begin{array}{l}\text { health }_{i t} \\
\text { hdi }_{i t}\end{array}$ & $\begin{array}{l}0.0325 \\
(0.513) \\
-1.3015 \\
(0.096) \\
\end{array}$ & $\begin{array}{l}-4.3751 * * \\
(0.000) \\
-4.5413 * * \\
(0.000) \\
\end{array}$ & $\begin{array}{l}-0.8521 \\
(0.238) \\
1.8256 \\
(0.092) \\
\end{array}$ & $\begin{array}{l}-3.5721 * * \\
(0.000) \\
-4.8040 * * \\
(0.000) \\
\end{array}$ & $\begin{array}{l}2.1408 \\
(0.984) \\
2.6355 \\
(0.921)\end{array}$ & $\begin{array}{l}-3.2369 * * \\
(0.001) \\
-4.9835 * * \\
(0.000) \\
\end{array}$ \\
\hline
\end{tabular}

Parenthesis shows $\mathrm{p}$-value and $* *$ shows $5 \%$ significance level. 
Table 5 shows the unit root tests of all variables of this study. The results of unit root testing are comparable as IPS, LLC, and Breitung show some different results at a level and first difference. On the other hand, Greenfield-FDI, trade, inflation, and health are stationary at the level, whereas the rest of the variables are not. At a $1 \%$ level of significance, the first difference of these variables becomes stationary. Especially IPS and LLC tests have the same results at a level and first difference. Only Greenfield-FDI remains stationary at level after using the Breitung test, while the rest becomes stationary at the difference.

Table 6: ARDL Model Long and Short Run Results of Dependent Variables (Education, Health, Income and HDI)

\begin{tabular}{|c|c|c|c|c|c|}
\hline \multirow{7}{*}{ LR } & Variables & $e^{e d u_{i t}}$ & health $_{i t}$ & income $_{i t}$ & $h d i_{i t}$ \\
\hline & GFDI $_{i t}$ & $\begin{array}{l}0.0381 * * \\
(0.031)\end{array}$ & $\begin{array}{l}0.0596 * * \\
(0.000)\end{array}$ & $\begin{array}{l}0.0123 * * \\
(0.000)\end{array}$ & $\begin{array}{l}0.0299 * * \\
(0.024)\end{array}$ \\
\hline & $\mathrm{rem}_{i t}$ & $\begin{array}{l}0.0001^{* *} \\
(0.021)\end{array}$ & $\begin{array}{l}0.0002^{* *} \\
(0.025)\end{array}$ & $\begin{array}{l}0.0003 * * \\
(0.000)\end{array}$ & $\begin{array}{l}7.85 \mathrm{E}-05^{* *} \\
(0.041)\end{array}$ \\
\hline & $\operatorname{aid}_{i t}$ & $\begin{array}{l}-0.0000 \\
(0.714)\end{array}$ & $\begin{array}{l}-0.0043 * * \\
(0.000)\end{array}$ & $\begin{array}{l}-0.0003 \\
(0.247)\end{array}$ & $\begin{array}{l}1.24 \mathrm{E}-05 \\
(0.833)\end{array}$ \\
\hline & $\operatorname{trade}_{i t}$ & $\begin{array}{l}7.41 \mathrm{E}-02 * * \\
(0.000)\end{array}$ & $\begin{array}{l}0.2136^{* *} \\
(0.003)\end{array}$ & $\begin{array}{l}0.0155 \\
(0.277)\end{array}$ & $\begin{array}{l}0.0743 \\
(0.000)\end{array}$ \\
\hline & pop $_{i t}$ & $\begin{array}{l}1.56 \mathrm{E}-08 * * \\
(0.000)\end{array}$ & $\begin{array}{l}4.95 \mathrm{E}-09 * * \\
(0.000)\end{array}$ & $\begin{array}{l}9.87 \mathrm{E}-10 * * \\
(0.000)\end{array}$ & $\begin{array}{l}8.39 \mathrm{E}-09 * * \\
(0.000)\end{array}$ \\
\hline & $\inf _{i t}$ & $\begin{array}{l}0.0012 * * \\
(0.012)\end{array}$ & $\begin{array}{l}0.0024 * * \\
(0.004)\end{array}$ & $\begin{array}{l}-0.0012 * * \\
(0.000)\end{array}$ & $\begin{array}{l}0.0018^{* *} \\
(0.003)\end{array}$ \\
\hline \multirow{8}{*}{ SR } & ECT & $\begin{array}{l}-0.1185^{* *} \\
(0.001)\end{array}$ & $\begin{array}{l}-0.0119 * * \\
(0.005)\end{array}$ & $\begin{array}{l}-0.1835 * * \\
(0.004)\end{array}$ & $\begin{array}{l}-0.0731 * * \\
(0.031)\end{array}$ \\
\hline & GFDI $_{i t}$ & $\begin{array}{l}0.0019 \\
(0.739)\end{array}$ & $\begin{array}{l}0.0025 \\
(0.512)\end{array}$ & $\begin{array}{l}0.0092 \\
(0.271) \\
\end{array}$ & $\begin{array}{l}0.0075 \\
(0.177) \\
\end{array}$ \\
\hline & $\mathrm{rem}_{i t}$ & $\begin{array}{l}-0.0002 \\
(0.061)\end{array}$ & $\begin{array}{l}-3.46 \mathrm{E}-05 * * \\
(0.016)\end{array}$ & $\begin{array}{l}-1.03 \mathrm{E}-05 \\
(0.898)\end{array}$ & $\begin{array}{l}-2.1 \mathrm{E}-05 \\
(0.727)\end{array}$ \\
\hline & $\operatorname{aid}_{i t}$ & $\begin{array}{l}0.0006 \\
(0.356)\end{array}$ & $\begin{array}{l}4.78 \mathrm{E}-05 \\
(0.094)\end{array}$ & $\begin{array}{l}-0.0001 \\
(0.224)\end{array}$ & $\begin{array}{l}8.74 \mathrm{E}-05 \\
(0.558)\end{array}$ \\
\hline & $\operatorname{trade}_{i t}$ & $\begin{array}{l}-0.0384 \\
(0.176)\end{array}$ & $\begin{array}{l}0.0007 \\
(0.774)\end{array}$ & $\begin{array}{l}0.0469 \\
(0.047)\end{array}$ & $\begin{array}{l}0.0058 \\
(0.591)\end{array}$ \\
\hline & pop $_{i t}$ & $\begin{array}{l}2.13 \mathrm{E}-09 \\
(0.915)\end{array}$ & $\begin{array}{l}-7.21 \mathrm{E}-09 \\
(0.359)\end{array}$ & $\begin{array}{l}-7.71 \mathrm{E}-08 \\
(0.225)\end{array}$ & $\begin{array}{l}-3.77 \mathrm{E}-08 \\
(0.315)\end{array}$ \\
\hline & $\inf _{i t}$ & $\begin{array}{l}-0.0001 \\
(0.421)\end{array}$ & $\begin{array}{l}0.0002 \\
(0.389)\end{array}$ & $\begin{array}{l}-1.96 \mathrm{E}-05 \\
(0.788)\end{array}$ & $\begin{array}{l}-0.0002 \\
(0.171)\end{array}$ \\
\hline & Constant & $\begin{array}{l}-0.0069 \\
(0.883)\end{array}$ & $\begin{array}{l}0.0086 \\
(0.052)\end{array}$ & $\begin{array}{l}0.1146 \\
(0.086)\end{array}$ & $\begin{array}{l}0.0199 \\
(0.143)\end{array}$ \\
\hline
\end{tabular}

Parenthesis shows $\mathrm{p}$-value and $* *$ shows $5 \%$ significance level.

Table 6 shows long-run results, revealing that Remittances and Greenfield FDI have a positive and significant impact on education. Aid and trade have insignificant negative and positive effects, respectively, whereas the population has negligible adverse effects on education. These findings are reinforced by the conclusions of (Lehnert et al., 2013), which found FDI to be beneficial for education.

Greenfield-FDI, remittances, trade and population have significantly positive impact on education but aid and inflation are negatively and insignificantly related to education. These outcomes are supported by the results of (Luu, 2016), (Zhuang, 2017) and (Raza et al., 2020). In the second model of this study, Greenfield-FDI, trade, and population have a significantly positive relationship with health, while remittances have an insignificant relationship. Aid and inflation have negligible but negative impacts on health. These findings are consistent with the results of (Raza et al., 2020). Greenfield-FDI has a favorable and significant impact on income in the third model of this study, as evidenced by studies by (Azam, 2019; Raza et al., 2021; Shrestha, 2013). Aid is negatively and insignificantly affects income, and identical results were found by (Lehnert et al., 2013). In the results of this study, inflation has a significant but negative effect, and the same was found by (Groot, 2014). According to the study's fourth model, Greenfield's FDI and trade have a positive and significant impact on socio-economic development. This impact is greater than that of 
remittances, aid, population, and inflation. The same results were found by studies of (Lehnert et al., 2013) and (Groot, 2014). Remittances, trade, population, and inflation have a statistically positive and significant impact on socio-economic development, whereas aid has an insignificant positive effect. The results of (Arisman, 2018; Ullah \& Azim, 2015) supported these results.

Table 6 shows the short-run effect of all independent variables on dependent variables in each model. The results are according to theory, the error correction term in all models is negative and statistically significant. A value of -0.12 in the education model indicates that $12 \%$ of the disequilibrium is dissolved in the education model before the following period, while the remaining $85 \%$ persists. Similarly, $1 \%$ of the disequilibrium is dissolved in the health model, $18 \%$ in the income model, and $7 \%$ in the human development index model. In the first model of this research, all independent variables are statistically insignificant GreenfieldFDI, remittance, trade, and inflation are negative, while aid and population are positively related to health. These short-term results are consistent with (Mustafa et al., 2017; Raza et al., 2020).

\section{Conclusions}

Various researchers have looked into the relationship between disaggregated FDI and developing country economic growth. The impact of Greenfield-FDI on health, education, income, and socioeconomic development in selected Asian countries is investigated in this study. For this purpose, panel data set of 10 sample countries from 1990-2017 has been used. The data was checked and found strongly balanced, and for unit root testing, IPS and ARDL techniques were applied. The study found that Greenfield-FDI has a long-run positive effect on the health, education, income, and socioeconomic development of Asian countries. After examining all these results and interpretations, it can indeed be concluded that policymakers and institutions concerned should take the importance of Greenfield-FDI investment seriously and make friendly policies to encourage foreign investors to invest. If Greenfield-FDI is not benefiting at the grassroots level like to spur income, education, and health, then the government must check its micro-level policies. Government must take the economy in the broad sense, and its focus should not be only on the attraction on Greenfield-FDI but also make enlivenment and infrastructure for investors. If governments can make such friendly policies, these new startup investments will positively impact the economy, health, education, and individual economic well-being of the host country's society.

\section{References}

Amoroso, S., \& Moncada-Paternò-Castello, P. (2018). Inward greenfield FDI and patterns of job polarization. Sustainability, 10(4), 1219.

Anand, S., \& Sen, A. (1994). Human Development Index: Methodology and Measurement.

Arisman, A. (2018). Determinant of human development index in ASEAN countries. Signifikan: Jurnal IImu Ekonomi, 7(1), 113-122.

Asghar, N., Qureshi, D. S., \& Nadeem, M. (2020). Institutional quality and economic growth: Panel ARDL analysis for selected developing economies of Asia. South Asian Studies, $30(2)$.

Ashraf, A., \& Herzer, D. (2014). The effects of greenfield investment and M\&As on domestic investment in developing countries. Applied Economics Letters, 21(14), 997-1000.

Ashraf, A., Herzer, D., \& Nunnenkamp, P. (2016). The effects of Greenfield FDI and cross-border M\&As on total factor productivity. The World Economy, 39(11), 17281755.

Azam, M. (2016). Does governance and foreign capital inflows affect economic development in OIC countries. Journal of Economic Cooperation and Development, 37(4), 21-50.

Azam, M. (2019). Relationship between energy, investment, human capital, environment, and economic growth in four BRICS countries. Environmental Science and Pollution Research, 26(33), 34388-34400.

Azam, M., \& Ahmed, A. M. (2015). Role of human capital and foreign direct investment in promoting economic growth: evidence from Commonwealth of Independent States. International Journal of Social Economics.

Azam, M., \& Gavrila, L. (2015). Inward foreign capital flows and economic growth in African countries. Journal of Applied Economic Sciences, 10(33), 362-371.

Bahattab, A. S., Azam, M., Gavrila, L., \& Emiruallah, C. (2016). Foreign capital inflows, 
institutional factors and economic growth: Evidences from Republic of Yemen. Journal of Applied Economic Sciences, 5(43), 811-816.

Barro, R. J. (1991). Economic growth in a cross section of countries. The Quarterly Journal of Economics, 106(2), 407-443.

Bayar, Y. (2017). Greenfield and brownfield investments and economic growth: evidence from central and Eastern European Union countries. Naše Gospodarstvo/Our Economy, 63(3), 19-26.

Byun, H.-S., Lee, H.-H., \& Park, C.-Y. (2012). Assessing factors affecting M\&As versus Greenfield FDI in emerging countries. Asian Development Bank Economics Working Paper Series, 293.

De Groot, O. (2014). Foreign Direct Investment and Welfare (LC/L. 3800). Santiago, Economic Commission for Latin America and the Caribbean (ECLAC).

Domar, E. D. (1946). Capital expansion, rate of growth, and employment. Econometrica, Journal of the Econometric Society, 137-147.

Dunning, J. H. (1979). Explaining changing patterns of international production: in defence of the eclectic theory. Oxford Bulletin of Economics and Statistics, 41(4), 269-295.

Eren, M., \& Zhuang, H. (2015). Mergers and acquisitions versus greenfield investment, absorptive capacity, and economic growth: Evidence from 12 new member states of the European Union. Eastern European Economics, 53(2), 99-123.

FDI. (2018). THE FDI REPORT 2018: Global greenfield investment trends, Report. The Financial Times Ltd.

Feder, G. (1983). On exports and economic growth. Journal of Development Economics, 12(12), 59-73.

Harms, P., \& Méon, P.-G. (2011). An FDI is an FDI is an FDI? The growth effects of greenfield investment and mergers and acquisitions in developing countries. working paper.

Harrod, R. (1972). An essay in dynamic theory. In Economic Essays (pp. 254-277). Springer.

Im, K. S., Pesaran, M. H., \& Shin, Y. (2003). Testing for unit roots in heterogeneous panels. Journal of Econometrics, 115(1), 53-74.

Kim, Y.-H. (2009). Cross-border M\&A vs. greenfield FDI: Economic integration and its welfare impact. Journal of Policy Modeling, 31(1), 87-101.

Krugman, P., \& Mankiw, N. G. (1995). Peddling prosperity: economic sense and nonsense in the age of diminished expectations. Journal of Economic Literature, 33(4), 1987-1988.

Kuznets, S. (1947). Measurement of economic growth. The Journal of Economic History, $7(\mathrm{~S} 1), 10-34$.

Layard, R. (2009). The 3rd OECD World Forum on "Statistics, Knowledge and Policy" Charting Progress, Building Visions, Improving Life. Korea: Busan.

Lehnert, K., Benmamoun, M., \& Zhao, H. (2013). FDI inflow and human development: analysis of FDI's impact on host countries' social welfare and infrastructure. Thunderbird International Business Review, 55(3), 285-298.

Loayza, N., Calderón, C. A., \& Servén, L. (2004). Greenfield foreign direct investment and mergers and acquisitions: Feedback and macroeconomic effects. Available at SSRN 636612.

Luu, H. (2016). Greenfield investments, cross-border M\&As, and economic growth in emerging countries. Economics and Business Letter, 5(3).

Luu, H. N., Nguyen, N. M., Ho, H. H., \& Nam, V. H. (2019). The effect of corruption on FDI and its modes of entry. Journal of Financial Economic Policy.

Mahmoud Khalid Almsafir, A. P., Abdul Latif, N. W. B., \& Bekhet, H. A. (2011). Analyzing the green field investment in Malaysia from 1970 to 2009: A bound testing approach.

Mankiw, N. G., Romer, D., \& Weil, D. N. (1992). A contribution to the empirics of economic growth. The Quarterly Journal of Economics, 107(2), 407-437.

Marinescu, N. (2016). Greenfields and acquisitions: a comparative analysis. Bulletin of the Transilvania University of Brasov. Economic Sciences. Series V, 9(1), 295.

Meyer, K. E. (2004). Perspectives on multinational enterprises in emerging economies. Journal of International Business Studies, 35(4), 259-276.

Moon, H.-C., Kim, H.-K., \& Lee, D.-H. (2003). Cross-border Mergers and Acquisitions: Case Studies of Korea, China, and Hong Kong, China. Asia-Pacific Economic Cooperation Secretariat.

Mukherjee, R. (2017). Foreign capital inflow and its welfare implications in a developing country context. Economics, 11(1).

Mustafa, G., Rizov, M., \& Kernohan, D. (2017). Growth, human development, and trade: The Asian experience. Economic Modelling, 61, 93-101. 
Neto, P., Brandão, A., \& Cerqueira, A. (2008). The impact of FDI, cross-border mergers and acquisitions, and greenfield investments on economic growth. The IUP Journal of Business Strategy, 24-44.

Nordhaus, W. D., Tobin, J., \& Moss, M. (1973). The Measurement of Economic and Social Performance. Studies in Income and Wealth, 38(3), 509-564.

Nunnenkamp, P., \& Spatz, J. (2003). Foreign direct investment and economic growth in developing countries: how relevant are host-country and industry characteristics? Kiel working paper.

Pesaran, M. H. (1997). The role of economic theory in modelling the long run. The Economic Journal, 107(440), 178-191.

Pesaran, M. H., Shin, Y., \& Smith, R. J. (2001). Bounds testing approaches to the analysis of level relationships. Journal of Applied Econometrics, 16(3), 289-326.

Pesaran, M. H., Shin, Y., \& Smith, R. P. (1999). Pooled mean group estimation of dynamic heterogeneous panels. Journal of the American Statistical Association, 94(446), 621634.

Pesaran, M. H., \& Smith, R. (1995). Estimating long-run relationships from dynamic heterogeneous panels. Journal of Econometrics, 68(1), 79-113.

Qizilbash, M. (2001). Sustainable development: Concepts and rankings. Journal of Development Studies, 37(3), 134-161.

Raza, A., Azam, M., \& Tariq, M. (2020). The Impact of Greenfield-FDI on Socio-Economic Development of Pakistan. Экономический Журнал Высшей Школы Экономики, 24(3).

Raza, A., Azam, M., Tariq, M., \& Sadiqa, B. A. (2021). An Empirical data investigation of the Greenfield investment: Welfare nexus from low-income countries. International Journal of Innovation, Creativity and Change, 15(8), 820-835.

RAZA, A. L. I., KHAN, M. A., \& TARIQ, M. (n.d.). A Panel Data Investigation of Greenfield Investment on the Welfare of African Developing Countries.

Romer, P. M. (1986). Increasing returns and long-run growth. Journal of Political Economy, 94(5), 1002-1037.

Romer, P. M. (1994). The origins of endogenous growth. Journal of Economic Perspectives, $8(1), 3-22$.

Sawyer, W. C., Sprinkle, R. L., \& Tochkov, K. (2010). Patterns and determinants of intraindustry trade in Asia. Journal of Asian Economics, 21(5), 485-493. https://doi.org/10.1016/j.asieco.2010.04.001

Sen, A. (1998). Mortality as an indicator of economic success and failure. The Economic Journal, 108(446), 1-25.

Sen, A. (2000). A decade of human development. Journal of Human Development, 1(1), 1723.

Shrestha, P. K. (2013). Economic development in South and East Asia: empirical examination of East Asian development model. Asia-Pacific Development Journal, 20(2), 1-28.

Slangen, A. H. L., \& Hennart, J.-F. (2008). Do multinationals really prefer to enter culturally distant countries through greenfields rather than through acquisitions? The role of parent experience and subsidiary autonomy. Journal of International Business Studies, 39(3), 472-490.

Stepanok, I. (2015). Cross-border mergers and greenfield foreign direct investment. Review of International Economics, 23(1), 111-136.

Todaro, M. P., \& Smith, S. C. (2015). Economic development (12th Editi). Pearson Education. New York.

UI Haq, M. (1995). Reflections on human development. oxford university Press.

Ullah, S., \& Azim, P. (2015). Human Development in the Era of Globalization: An Asian Perspective. XIV International Business and Economy Conference (IBEC) Bangkok, Thailand.

UNCTAD. (2017). Global value chains: Investment and trade for development. World Investment Report. New York: United Nations, 121-202. https://doi.org/10.18356/f045c54c-en

UNCTAD S. (2020). Unctad Stat Data Center. World Statistical Database.[Online]. Available at: Https://Bit. Ly/21GbfKX [Accessed: 2020, January 15].

UNDP. (2020). Human Development Report (2020): Beyond income, beyond averages, beyond today. New York.

Vernon, R. (1966). International investment and intemational trade in the product cycle), Quaterly Journal of Economics, n. 80. 
Wang, M., \& Sunny Wong, M. C. (2009). What drives economic growth? The case of cross-border M\&A and greenfield FDI activities. Kyklos, 62(2), 316-330.

WDI, T. (2019). World development indicators (DataBank).

Zhuang, H. (2017). The effect of foreign direct investment on human capital development in East Asia. Journal of the Asia Pacific Economy, 22(2), 195-211.

Zhuang, H., \& Griffith, D. (2013). The effect of mergers \& acquisitions and greenfield FDI on income inequality. 